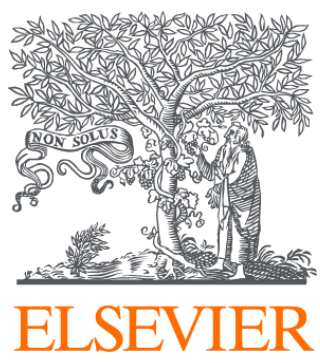

Since January 2020 Elsevier has created a COVID-19 resource centre with free information in English and Mandarin on the novel coronavirus COVID-

19. The COVID-19 resource centre is hosted on Elsevier Connect, the company's public news and information website.

Elsevier hereby grants permission to make all its COVID-19-related research that is available on the COVID-19 resource centre - including this research content - immediately available in PubMed Central and other publicly funded repositories, such as the WHO COVID database with rights for unrestricted research re-use and analyses in any form or by any means with acknowledgement of the original source. These permissions are granted for free by Elsevier for as long as the COVID-19 resource centre remains active. 
Research Notes

\title{
Gender inequality during the COVID-19 pandemic: Income, expenditure, savings, and job loss
}

\author{
Hai-Anh H. Dang ${ }^{\mathrm{a}, \mathrm{b}}$, Cuong Viet Nguyen ${ }^{\mathrm{c}, \mathrm{d}, *}$ \\ ${ }^{a}$ Data Production \& Methods Unit, Development Data Group, World Bank, United States \\ ${ }^{\mathrm{b}}$ Vietnam Academy of Social Sciences, Hanoi, Viet Nam \\ ${ }^{\mathrm{c}}$ International School, Vietnam National University, Hanoi, Viet Nam \\ ${ }^{\mathrm{d}}$ Mekong Development Research Institute, Hanoi, Viet Nam
}

\section{A R T I C L E I N F O}

\section{Article history:}

Available online 10 November 2020

\section{JEL classifications:}

J16

J21

012

Keywords:

COVID-19

Gender gap

Income

Employment

Job loss

\begin{abstract}
A B S T R A C T
The COVID-19 outbreak has brought unprecedented disruptions to the global economies and has led to income loss and high unemployment rates. But scant, if any, evidence exists on gender gaps in economic outcomes such as income, expenditure, savings, and job loss in a multi-country setting. We investigate the impacts of COVID-19 on gender inequality in these outcomes using data from a sixcountry survey that covers countries in different geographical locations and at various income levels. Our findings suggest that women are 24 percent more likely to permanently lose their job than men because of the outbreak. Women also expect their labor income to fall by 50 percent more than men do. Perhaps because of these concerns, women tend to reduce their current consumption and increase savings. Factors such as the different participation rates in work industries for men and women may take an important part in explaining these gender gaps. Our estimates also point to country heterogeneity in these gender differences that is likely due to varying infection rates and shares of women in the labor force.
\end{abstract}

(c) 2020 Elsevier Ltd. All rights reserved.

\section{Introduction}

Gender inequality is a challenge in richer and poorer country alike (Duflo, 2012). A recent report by the United Nations suggests that on average, 18 percent of ever-partnered women and girls aged 15 to 49 have experienced physical and/or sexual partner violence in the previous 12 months, but the prevalence is even higher in least developed countries (United Nations, 2019). Wellrecognized solutions to this challenge are to empower women financially and provide them with productive employment opportunities. Indeed, a steadily growing and increasingly diversified economy can create jobs in different sectors such as health and services that can bring about these opportunities.

But the COVID-19 outbreak has generated unprecedented disruptions to the global economies, which in turns led to income loss and high unemployment rates. A recent study raises the possibilities that these negative effects could have wiped out the global

\footnotetext{
* Corresponding author at: International School, Vietnam National University, Hanoi, Viet Nam.

E-mail addresses: hdang@worldbank.org (H.-A.H. Dang), cuongnv@isvnu.vn (C. Viet Nguyen).
}

progress in poverty reduction for the past 30 years (Sumner, Hoy, \& Ortiz-Juarez, 2020). Should we expect similarly harmful impacts on gender inequality, particularly in terms of economic outcomes such as income, savings, and job loss? If past experience can offer any guidance, women suffered lower unemployment rates than men in the Great Recession in the United States and their employment generally tends to be less cyclical than that of men (Hoynes, Miller, \& Schaller, 2012; Doepke \& Tertilt, 2016). Yet, Alon et al. (2020) argue that the COVID-19 pandemic differs from a typical economic recession since it can more strongly affect sectors with high female employment shares. ${ }^{1}$ As such, opposing forces may be at work regarding female employment during the COVID-19 pandemic, and the net impacts on their income and employment rates can be an empirical question.

While some recent limited evidence indicates that the pandemic can affect women's labor market prospects more than men in the United States (Cajner et al., 2020) and the United Kingdom

\footnotetext{
1 Alon et al. (2020) also observe another channel of impacts of COVID-19 such as increased need of childcare for mothers due to school closures. But in the future, more flexible business practices or changing social norms for childcare and domestic work can occur.
} 
(Hupkau \& Petrongolo, 2020), very few studies currently exist on the pandemic impacts on gender inequality in a multi-country setting. ${ }^{2}$ Analyzing real-time surveys conducted between late March and mid-April in 12 countries, Foucault and Galasso (2020) find women to stop working more than men during the pandemic in various countries such as Austria, Canada, Germany, Italy, Poland and Sweden. Yet, their analysis only consists of descriptive statistics of the gender gap. To our knowledge, the only exception that offers a more in-depth analysis is Adams-Prassl, Boneva, Golin, and Rauh (2020), which finds women to be significantly more likely to lose their jobs in the United States and United Kingdom, but not in Germany. Adams-Prassl et al. (2020) also observes that women who did not lose their job were no more likely to experience a fall in their income compared to men in all three countries.

We aim to fill in this gap in the literature and investigate the impacts of COVID-19 on gender inequality in income and employment outcomes using rich micro data from a six-country survey. The survey was implemented during the COVID-19 pandemic in late April 2020 and covered countries in different geographical locations and at various income levels including China, Italy, Japan, South Korea, the United Kingdom, and the United States.

Our findings suggest that although no gender differences exist with the COVID-19 impacts on temporary job loss, women are 24 percent more likely to permanently lose their job compared to men. Women also worry more about the future effects of COVID19 on their own labor income: they expect their labor income to fall by 50 percent more than men do. Perhaps because of these concerns, women tend to reduce their current consumption and increase savings. Factors such as gender differences in employment industries may take an important part in explaining the gender gaps in expected income loss, expenditure, and savings. Our estimates also point to country heterogeneity in these gender differences that is likely due to different COVID-19 infection rates and the shares of women participation in the labor force.

This paper consists of five sections. We describe the data in the next section before discussing our analytical framework in Section 3. We offer the estimation results in Section 4 and finally conclude in Section 5.

\section{Data}

In this study, we use data from nationally representative samples across 6 countries including China, South Korea, Japan, Italy, the United Kingdom and the four largest states in the United States (California, Florida, New York, and Texas). This data set was collected by Belot et al. (2020) with funding from the CreativePioneering Researchers Program at Seoul National University, and from the European University Institute. The survey was implemented between April 15 and April 23. The sample size is 6089 respondents, of which 3138 respondents are female, accounting for $51.5 \%$ of the sample. The sample size of each country is around 1000, ranging from 963 for South Korea to 1055 for the United States. In each country, the samples are nationally representative for age groups, gender, and household income quintiles (Belot et al., 2020). The survey contains information on basic demographic variables of respondents, employment and living situations, health and diseases, self-reports on economic and noneconomic consequences of the pandemic, behavior, beliefs about the pandemic and responses of the governments.

\footnotetext{
${ }^{2}$ Other studies that focus on specific countries include Farré et al. (2020) on Spain and Sevilla and Smith (2020) on the United Kingdom. While Farré et al. (2020) find the covid-19 crisis appears to have increased gender inequalities in both paid and unpaid work in the short-term, Sevilla and Smith (2020) find that the difference between the share of childcare done by women and the share done by men narrow after the pandemic.
}

Table 1

Gender differences in the outcome variables.

\begin{tabular}{lllc}
\hline Outcomes & Female & Male & Difference \\
\cline { 2 - 4 } & $(1)$ & $(2)$ & $(3)$ \\
\hline \% people losing job permanently & $5.8^{* * *}$ & $4.9^{* * *}$ & 0.9 \\
& $(0.4)$ & $(0.4)$ & $(0.6)$ \\
\% people losing job temporarily & $24.6^{* * *}$ & $25.0^{* * *}$ & -0.4 \\
& $(0.8)$ & $(0.8)$ & $(1.1)$ \\
Log of expected income reduction & $4.170^{* * *}$ & $3.799^{* * *}$ & $0.371^{* * *}$ \\
& $(0.097)$ & $(0.089)$ & $(0.132)$ \\
Increased weekly expenses & $2.487^{* * *}$ & $2.550^{* * *}$ & $-0.063^{* *}$ \\
& $(0.021)$ & $(0.021)$ & $(0.030)$ \\
Increased savings & $2.524^{* * *}$ & $2.464^{* * *}$ & $0.060^{* *}$ \\
\multirow{2}{*}{ Number of observations } & $(0.020)$ & $(0.019)$ & $(0.027)$ \\
\hline
\end{tabular}

Standard errors in parentheses.

${ }^{* * *} \mathrm{p}<0.01,{ }^{* *} \mathrm{p}<0.05,{ }^{*} \mathrm{p}<0.1$ : denote the statistical levels of difference from zero.

To examine the representativeness of the survey at the country level, we compare the distributions of respondents by gender and age groups in the survey and the distributions of these characteristics obtained from the official figures (Table A.1 in Appendix). There are some differences in the proportion of respondents in age groups for Japan and UK. However, the differences are not large. Another way to look at the representativeness of the survey is to examine the distributions of respondents by income quintiles (Table A.2 in Appendix A). The survey did not collect data on respondents' specific incomes, but collected data on which of the five pre-COVID-19 income brackets (quintiles) they belong to. ${ }^{3}$ If the COVID-19 survey samples are representative of these income quintiles, the proportion of respondents in each quintile should be $20 \%$. Table A.2 shows that the proportions of respondents in each income quintile in the six countries are not identical, but roughly close to $20 \%$.

Table 1 presents compare the mean outcomes between men and women for the six countries in the survey, with the gender differences for each country being reported in Table A.3 in Appendix A. Table 1 shows that $5.8 \%$ of women and $4.8 \%$ of men reported losing their job permanently, while around $25 \%$ of women and men reported losing their job temporarily. Unfortunately, the survey did not collect data on whether respondents experienced a fall in their wages or income, but it has a question on how much respondents expect their income to fall in the future. Overall, women are more concerned about the fall in their future income than men.

To assess the impacts of COVID-19 on expenditure and saving behaviors, the survey asked respondents on the relative changes in their weekly expenses and savings compared with January. The responses are coded from 1 to $5: 1=$ Drop of more than $10 \%$; $2=$ Drop of $<10 \% ; 3=$ No change; $4=$ Increase of $<10 \% ; 5=$ Increase of more than $10 \%$. If there are no effects of COVIDs, the averages of these variables should be equal to 3 . Higher values of these variables mean better expenses and savings. The averages of these variables are $<3$, which point to negative effects of COVID-19 on expenditure and savings. Compared with men, women are more affected in terms of expenditure but less affected in terms of savings.

\section{Econometric method}

To examine the gender difference in response to COVID-19, we regress the outcome variables on the gender and control variables:

\footnotetext{
${ }^{3}$ These income brackets are obtained by calculating quintiles of the gross household income distribution from the last available wave of nationally representative household surveys or census data, which capture the income distributions before the COVID-19 pandemic (Belot et al. 2020).
} 
Table 2

OLS regression of outcomes on gender.

\begin{tabular}{|c|c|c|c|c|c|}
\hline \multirow[t]{2}{*}{ Specification models } & \multicolumn{5}{|l|}{ Dependent variables } \\
\hline & Lost job permanently & Lost job temporarily & Log of expected income reduction & Increased weekly expenses & Increased savings \\
\hline \multirow[t]{2}{*}{ Model 1} & $0.010^{*}$ & -0.005 & $0.339^{* * *}$ & $-0.055^{*}$ & $0.065^{* *}$ \\
\hline & $(0.006)$ & $(0.011)$ & $(0.129)$ & $(0.030)$ & $(0.027)$ \\
\hline \multirow[t]{2}{*}{ Model 2} & $0.012^{* *}$ & 0.002 & $0.461^{* * *}$ & $-0.063^{* *}$ & $0.062^{* *}$ \\
\hline & $(0.006)$ & $(0.011)$ & $(0.128)$ & $(0.030)$ & $(0.027)$ \\
\hline \multirow[t]{2}{*}{ Model 3} & $0.012^{* *}$ & 0.003 & $0.453^{* * * *}$ & $-0.066^{* *}$ & $0.060^{* *}$ \\
\hline & $(0.006)$ & $(0.011)$ & $(0.129)$ & $(0.030)$ & $(0.027)$ \\
\hline \multirow[t]{2}{*}{ Model 4} & $0.013^{* *}$ & 0.007 & $0.448^{* * *}$ & $-0.065^{* *}$ & $0.053^{*}$ \\
\hline & $(0.006)$ & $(0.011)$ & $(0.129)$ & $(0.030)$ & $(0.027)$ \\
\hline
\end{tabular}

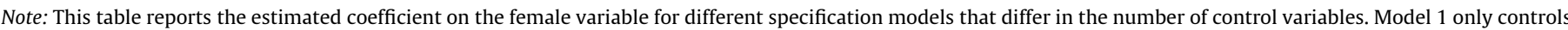

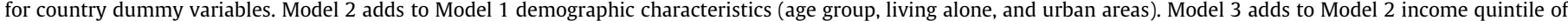
respondents. Model 4 adds to Model 3 the geographic region fixed-effects. The full regression results of Model 4 are reported in Table A.4 in Appendix A. Robust standard errors in parentheses

*** $\mathrm{p}<0.01,{ }^{* *} \mathrm{p}<0.05,{ }^{*} \mathrm{p}<0.1$

$Y_{i, j}=\alpha+$ Female $_{i, j} \beta+X_{i, j} \gamma+u_{i, j}$

where $Y_{i, j}$ a dependent variable of interest of individual $i$ in country $j$. Female $_{i, j}$ is a dummy variable that equals 1 for women and 0 otherwise. The control variables, $X$, include demographic characteristics and country dummy variables. $u_{i, j}$ denotes unobserved variables. It should be noted that the dependent variables in this study are self-reported changes in employment, income, expenditure and savings due to the COVID-19 pandemic. The 'female' variable measures the differences in the effect of the COVID-19 pandemic between men and women.

We also use an Oaxaca-Blinder decomposition technique to examine factors associated with the gender gap in outcome variables (Blinder, 1973; Oaxaca, 1973). We first run separate regressions of an outcome variable on the explanatory variables for men and women:

$Y_{m}=\alpha_{m}+X_{m} \beta_{m}+u_{m}$

$Y_{f}=\alpha_{f}+X_{f} \beta_{f}+u_{f}$

The subscript $i, j$ is dropped for simplicity. Subscripts ' $m$ ' and ' $f$ denote male and female, respectively.

To avoid the index problem in which the choice of the reference group affects decomposition results, we use the neutral coefficients in decomposition analysis as follows (see e.g., Jann \& Zürich, 2008):

$$
\begin{aligned}
\bar{Y}_{f}-\bar{Y}_{m}= & \left(\widehat{\alpha}_{f}+\bar{X}_{f} \widehat{\beta}_{f}\right)-\left(\widehat{\alpha}_{m}+\bar{X}_{m} \widehat{\beta}_{m}\right) \\
= & {\left[\left(\bar{X}_{f}-\bar{X}_{m}\right) \widehat{\beta}^{*}\right] } \\
& +\left[\bar{X}_{f}\left(\widehat{\beta}_{f}-\widehat{\beta}^{*}\right)+\bar{X}_{m}\left(\widehat{\beta}^{*}-\widehat{\beta}_{m}\right)+\left(\widehat{\alpha}_{f}-\widehat{\alpha}_{m}\right)\right]
\end{aligned}
$$

where $\hat{\alpha}$ and $\hat{\beta}$ are the estimated parameters from Eqs. (2) and (3). $\bar{X}_{m}$ and $\bar{X}_{f}$ are the average of explanatory variables of men and women. $\hat{\beta}^{*}$ is a vector of the estimated coefficients of the explanatory variables using pooled data on men and women.

The first term $\left(\bar{X}_{f}-\bar{X}_{m}\right) \hat{\beta}^{*}$ measures the difference in the outcome between women and men due to their differences in the observed explanatory variables. This is called the endowment effect or explained component. The remaining term is the gender difference caused by other factors than the differences in the observed explanatory variables. It includes differences in the return of observed variables (i.e., differences in the coefficients of explanatory variables in the regression) and differences in the unobserved characteristics between women and men. This component is referred to as the "unexplained component". It can also be regarded as a proxy of gender discrimination.

\section{Empirical results}

\subsection{Gender difference in the COVID impacts}

Table 2 reports the estimated coefficients on the female variable in the OLS regressions of the economic outcomes on this variable and other control variables including basic demography, geographic variables, and income quintiles. In an attempt to understand mechanisms and examine the sensitivity of the estimate, we use different model specifications which sequentially add different control variables. More specifically, Model 1 only controls for country dummy variables. Model 2 adds to Model 1 basic demographic variables including age groups and living alone. Model 3 adds to Model 2 geographic variables including urban dummy and region fixed-effects (there are 82 regions in the six countries). Model 4, which is the model with the most control variables and our preferred model for interpretation, adds income quintiles to Model 3. Table 2 presents only the coefficients of female. In Table A.4 in Appendix, we report the full results of Model 4.

The estimation results show that women are more likely to lose their jobs permanently than men, which are similar across the four models. According to Model 4, the probability of losing a job permanently due to the COVID-19 pandemic is 0.013 higher for women than for men. Since the average percentage of losing a job permanently is $5.4 \%$ for the whole sample, this is a relatively large difference and roughly equivalent to a 24-percent differential.

There are no gender differences in COVID-19 impacts on 'losing job temporarily'. However, women are more concerned about the future effects of COVID-19 on their own expected income. Women predict their income to fall in the next 6 months around 50\% more than the income fall predicted by men. ${ }^{4}$ Expecting a large income fall in the future, women tend to reduce their current consumption and increase savings. This finding is consistent with the hypothesis that women are perceived to be more risk-averse than men (see, e.g., Croson \& Gneezy, 2009). Several empirical studies also show that women tend to save more than men (Lee \& Pocock, 2007; Kureishi \& Wakabayashi, 2013).

A possible interpretation of the results in Table 2 is that women have a remarkably higher rate of working in services jobs than men in the six countries covered in the survey. This gender gap ranges from more than 10 percent for China to more than 20 percent for the United Kingdom and the United States (Fig. A.1 in

\footnotetext{
4 The estimated coefficient on the female variable in column 3 of Table 2 is 0.427 Since the dependent variable is in log form, the effect can be computed as $\exp (0.427)$ $-1=0.532$.
} 
Table 3

Decomposition analysis using the pooled sample.

\begin{tabular}{|c|c|c|c|c|}
\hline \multirow[t]{3}{*}{ Components } & \multicolumn{4}{|l|}{ Dependent variables } \\
\hline & Lost job permanently & Log of expected income reduction & Increased weekly expenses & Increased savings \\
\hline & $(1)$ & (3) & $(4)$ & $(5)$ \\
\hline Female & $\begin{array}{l}0.058^{* * *} \\
(0.004)\end{array}$ & $\begin{array}{l}4.170^{* * *} \\
(0.097)\end{array}$ & $\begin{array}{l}2.487^{* * *} \\
(0.021)\end{array}$ & $\begin{array}{l}2.524^{* * *} \\
(0.020)\end{array}$ \\
\hline Male & $\begin{array}{l}0.049^{* * *} \\
(0.004)\end{array}$ & $\begin{array}{l}3.799^{* * * *} \\
(0.089)\end{array}$ & $\begin{array}{l}2.550^{* * *} \\
(0.021)\end{array}$ & $\begin{array}{l}2.464^{* * *} \\
(0.019)\end{array}$ \\
\hline Difference & $\begin{array}{l}0.009 \\
(0.006)\end{array}$ & $\begin{array}{l}0.371^{* * * *} \\
(0.132)\end{array}$ & $\begin{array}{l}-0.063^{* *} \\
(0.030)\end{array}$ & $\begin{array}{l}0.060^{* *} \\
(0.027)\end{array}$ \\
\hline Explained & $\begin{array}{l}-0.004^{* *} \\
(0.002)\end{array}$ & $\begin{array}{l}-0.076 \\
(0.047)\end{array}$ & $\begin{array}{l}0.001 \\
(0.008)\end{array}$ & $\begin{array}{l}0.007 \\
(0.008)\end{array}$ \\
\hline Unexplained & $\begin{array}{l}0.013^{* *} \\
(0.006)\end{array}$ & $\begin{array}{l}0.448^{* * *} \\
(0.128)\end{array}$ & $\begin{array}{l}-0.065^{* *} \\
(0.030)\end{array}$ & $\begin{array}{l}0.053^{* *} \\
(0.027)\end{array}$ \\
\hline Observations & 6,089 & 6,089 & 6,089 & 6,089 \\
\hline
\end{tabular}

Robust standard errors in parentheses.

*** $\mathrm{p}<0.01,{ }^{* *} \mathrm{p}<0.05,{ }^{*} \mathrm{p}<0.1$.

Appendix A). Since the service sector is more affected by COVID-19 than other sectors (OECD, 2020), this could explain why women are more affected than men. ${ }^{5}$

Table 3 reports the decomposition of the gender difference in COVID-19 impacts into the explained and unexplained components. The 'female' variable is statistically significant in regressions of four dependent variables (Table 2), and we conduct decomposition analysis for these dependent variables. The explanatory variables include age groups, urban areas, regions, and income quintiles. Table A.6 in Appendix presents separate regressions for women and men (Eqs. (2) and (3)). The full results from the decomposition are lengthy. Thus we focus on the results of the decomposition of the gender gap in the outcomes into the explained and unexplained components. In the decomposition of the job loss, the explained component that is due to differences in individual characteristics is negative. On the other hand, the unexplained component is positive and significant. ${ }^{6}$

Women are more pessimistic about their future income than men. The gender difference in the expected income loss is mainly accounted for by the unexplained component. Regarding savings, women are less affected by COVID- 19 than men. The negative sign of the explained component means women appear more affected by COVID-19 than men in terms of observed characteristics. The unexplained component is 0.086 , which equals $140 \%$ of the total difference. This implies that unobserved factors cause women to save more than men during the COVID-19 pandemic.

\footnotetext{
5 The survey collects data on the industries that survey respondents work in, but there is a larger proportion of missing values for the industry variable (33\%). Consequently, for additional reference we show the estimation results when we control for the industry fixed effects in Table A.5 (Appendix 5). To ensure the maximal number of observations for the regressions in Table A.5, we create a separate industry code to pool together observations with missing values. This table suggests that once we control for differences in work industries, only the results that women lost jobs and saved more than men are statistically significant. Yet, these results should be taken with caution given the large proportion of missing vales.

${ }^{6}$ We offer more insights into the contributions of groups of specific explanatory variables (in the explained part) to the gender difference with Figure A.2. In particular, the difference in the proportion of permanent job loss between women and men is 0.009 . The total explained component of the age group dummy variables is estimated at -0.0022 , which equals $24 \%$ of the total gender gap. Figure A.2 also shows that the differences in age and geographic areas (urban and region dummies) between women and men help reduce the gender gap in the COVD-19 pandemic impacts by $7 \%$ and $16 \%$ respectively.

7 Model 4 controls for income quintiles. The control variables should be exogenous and not be affected by gender as well as the COVID-pandemic (Angrist and Pischke, 2008). Thus we also try to estimate Model 3, which do not control income quintiles. The results from Model 3 are very similar to those from Model 4.
}

\subsection{Heterogeneous effects across countries}

Next, we run regression of the outcome variables on gender and the control variables for each country using Model 4 in Table $2 .^{7}$ Fig. 1 presents the estimated coefficients on the female variable for each country. The gender difference in the effects of the COVID-19 pandemic on job loss is larger in China, Italy and the United States than in Japan, South Korea and the United Kingdom. There are no significant effects of gender on the probability of losing job temporarily in most countries. Only in United Kingdom, women are more likely to lose job temporarily than men. Women in both the United Kingdom and the United States experienced more decreases in weekly expenses than men. Regarding expected income falls, the effects of the COVID-19 pandemic are larger for women than men in Japan, the United Kingdom and the United States. Overall, Fig. 1 indicates the effects of the COVID-19 pandemic appear larger for women than men in China, Italy, the United Kingdom, and the United States.

It might be useful to examine the linkage between COVID-19 infection rates and the impacts of the pandemic. There are no statistically significant differences in economic losses due to the COVID-19 pandemic between men and women in Japan and South Korea, which have a lower COVID-19 infection rate than the other four countries. As of the third week of April 2020 (i.e., when the survey was implemented), the number of COVID-19 cases per 1000 people in Japan and South Korea was 0.11 and 0.21 , respectively. These are far lower than the corresponding figures of 3.4, 2.5, and 3.2 for Italy, the United Kingdom, and the United States. Although China has an even lower rate than the other countries ( 0.06 per 1000 people), this country had applied a social distancing policy for a longer time.

To further investigate whether women are more affected by the pandemic in countries with a higher COVID-19 rate, we include the interaction between the female variable and the COVID-19 infection rate (per thousand people). It should be noted that the COVID-19 infection rate is at the country level, so we cannot control for the country dummy variables in these regressions together with the interactions because of multicollinearity. Table 4 shows that the interaction terms are positive and statistically significant for the regressions of job loss and expected income reduction. This suggests that women are more affected than men in countries with a higher COVID-19 infection rate.

We also examine in Table 4 whether differences in the labor force participation can result in gender differences across countries. We include the interaction between the female variable and the share of women in the labor force for each country. The interaction terms are statistically significant for expected income 
Panel A. Lost job permanently

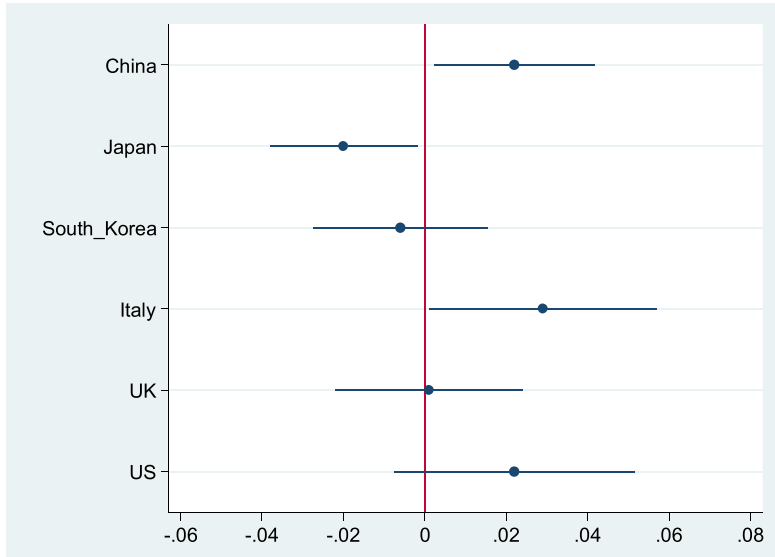

Panel C. Log of expected income reduction

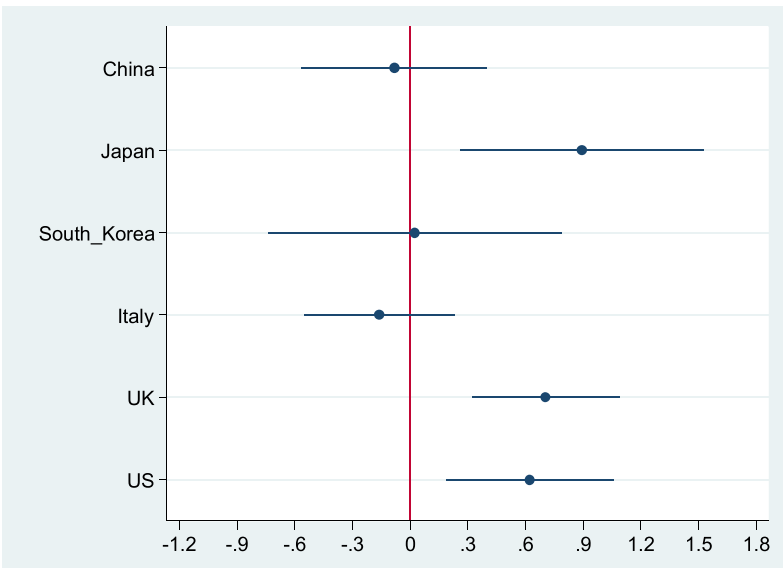

Panel B. Lost job temporarily

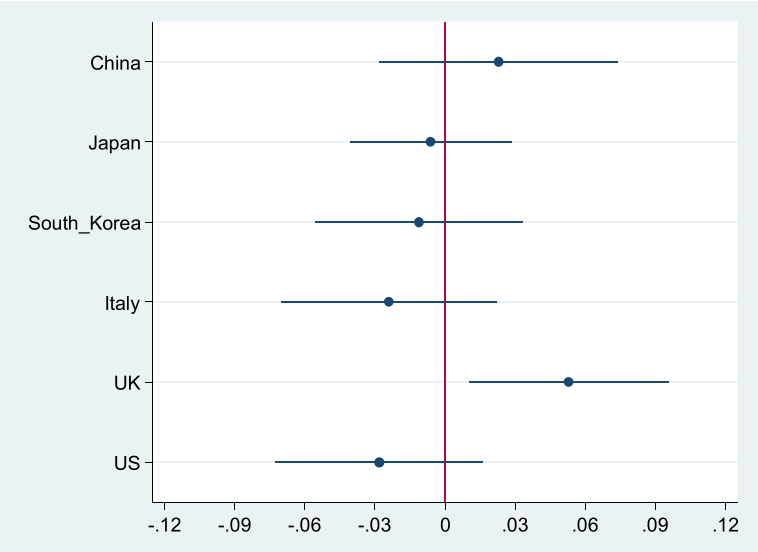

Panel D. Increased weekly expenses

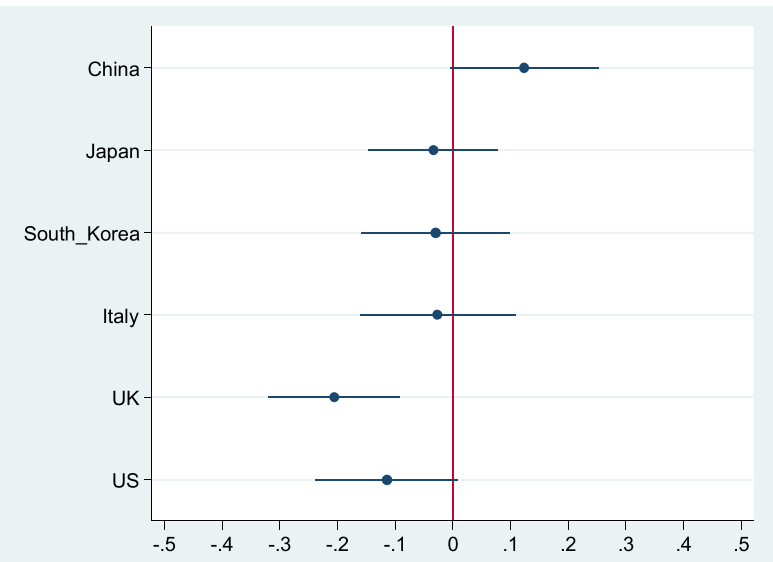

Panel E. Increased savings

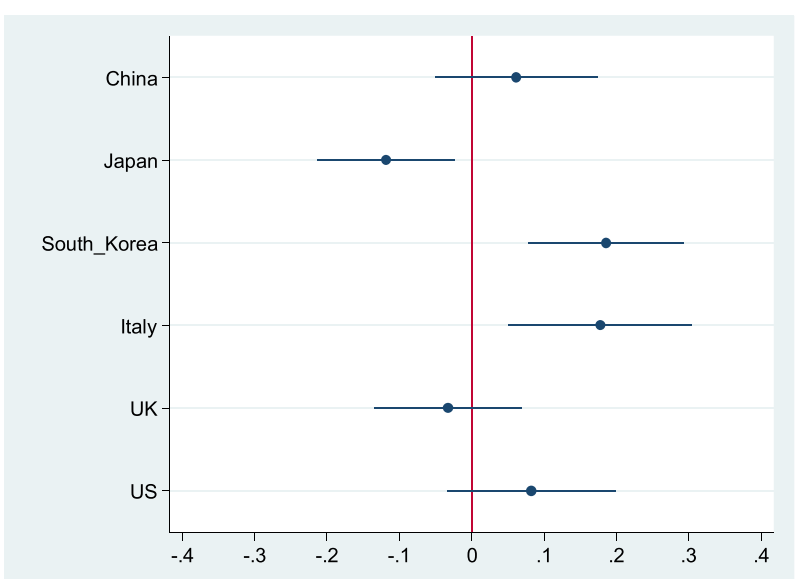

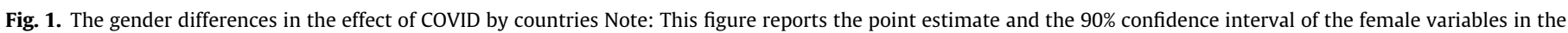
regression of outcomes in 6 countries.

reduction and weekly expenses. The sign of the interaction terms in these regressions indicates that women in countries with a higher share of women in the labor force expect more reduced income and weekly expenses.

\section{Conclusion}

We offer one of the first studies on the negative impacts of the COVID-19 pandemic on gender inequality in terms of income, 
Table 4

Regressions of outcomes with interactions.

\begin{tabular}{|c|c|c|c|c|c|c|}
\hline \multirow[t]{2}{*}{ Explanatory variables } & \multicolumn{6}{|c|}{ Dependent variables } \\
\hline & $\begin{array}{l}\text { Lost job } \\
\text { permanently }\end{array}$ & $\begin{array}{l}\text { Log of expected income } \\
\text { reduction }\end{array}$ & $\begin{array}{l}\text { Increased weekly } \\
\text { expenses }\end{array}$ & $\begin{array}{l}\text { Lost job } \\
\text { permanently }\end{array}$ & $\begin{array}{l}\text { Log of expected income } \\
\text { reduction }\end{array}$ & $\begin{array}{l}\text { Increased weekly } \\
\text { expenses }\end{array}$ \\
\hline Female $($ female $=1$, others $=0$ ) & $\begin{array}{l}0.007 \\
(0.006)\end{array}$ & $\begin{array}{l}0.359^{* *} \\
(0.140)\end{array}$ & $\begin{array}{l}-0.061^{*} \\
(0.032)\end{array}$ & $\begin{array}{l}-0.095 \\
(0.156)\end{array}$ & $\begin{array}{l}-7.494^{* *} \\
(3.295)\end{array}$ & $\begin{array}{l}1.931^{* *} \\
(0.787)\end{array}$ \\
\hline $\begin{array}{l}\text { Female * COVID case rate (per } \\
\text { thousand people) }\end{array}$ & $\begin{array}{l}0.003^{* *} \\
(0.001)\end{array}$ & $\begin{array}{l}0.047^{* *} \\
(0.022)\end{array}$ & $\begin{array}{l}-0.002 \\
(0.006)\end{array}$ & & & \\
\hline $\begin{array}{l}\text { Female * Share of female labor } \\
\text { force }\end{array}$ & & & & $\begin{array}{l}0.002 \\
(0.004)\end{array}$ & $\begin{array}{l}0.180^{* *} \\
(0.074)\end{array}$ & $\begin{array}{l}-0.045^{* *} \\
(0.018)\end{array}$ \\
\hline Control variables & Yes & Yes & Yes & Yes & Yes & Yes \\
\hline Constant & $\begin{array}{l}0.049^{* * *} \\
(0.013)\end{array}$ & $\begin{array}{l}3.805^{* * *} \\
(0.291)\end{array}$ & $\begin{array}{l}2.533^{* * *} \\
(0.071)\end{array}$ & $\begin{array}{l}0.049^{* * *} \\
(0.013)\end{array}$ & $\begin{array}{l}3.796^{* * *} \\
(0.291)\end{array}$ & $\begin{array}{l}2.536^{* * *} \\
(0.070)\end{array}$ \\
\hline Observations & 6,089 & 6,089 & 6,089 & 6,089 & 6,089 & 6,089 \\
\hline R-squared & 0.044 & 0.101 & 0.043 & 0.043 & 0.101 & 0.044 \\
\hline
\end{tabular}

Robust standard errors in parentheses.

${ }^{* * *} \mathrm{p}<0.01,{ }^{* *} \mathrm{p}<0.05,{ }^{*} \mathrm{p}<0.1$.

expenditure, savings, and job loss in a multi-country setting. Our estimation results suggest that women are more likely to permanently lose their job than men, and they expect their own labor income to fall more in the future than men do. We also find that women tend to reduce their current consumption and increase savings. Gender differences in the participation rate in the services industry may account for part of the gender gap. We find heterogeneous effects of the COVID-19 pandemic on women across countries. This finding suggests that governments should have policies to support women, and these policies can be tailored to specific countries.

\section{Declaration of Competing Interest}

The authors declare that they have no known competing financial interests or personal relationships that could have appeared to influence the work reported in this paper.

\section{Acknowledgements}

Dang (hdang@worldbank.org) is a senior economist with the Data Production \& Methods Unit, Development Data Group, World Bank and is also affiliated with GLO, IZA, Indiana University, and Vietnam Academy of Social Sciences; Nguyen (cuongnv@isvnu. vn) is a researcher in International School, Vietnam National University, and Mekong Development Research Institute, Hanoi, Vietnam. We would like to thank the editor Arun Agrawal, two anonymous reviewers, Long T. Giang, and Dean Jolliffe for useful feedback on earlier versions.

\section{Appendix A. Additional Tables and Figures}

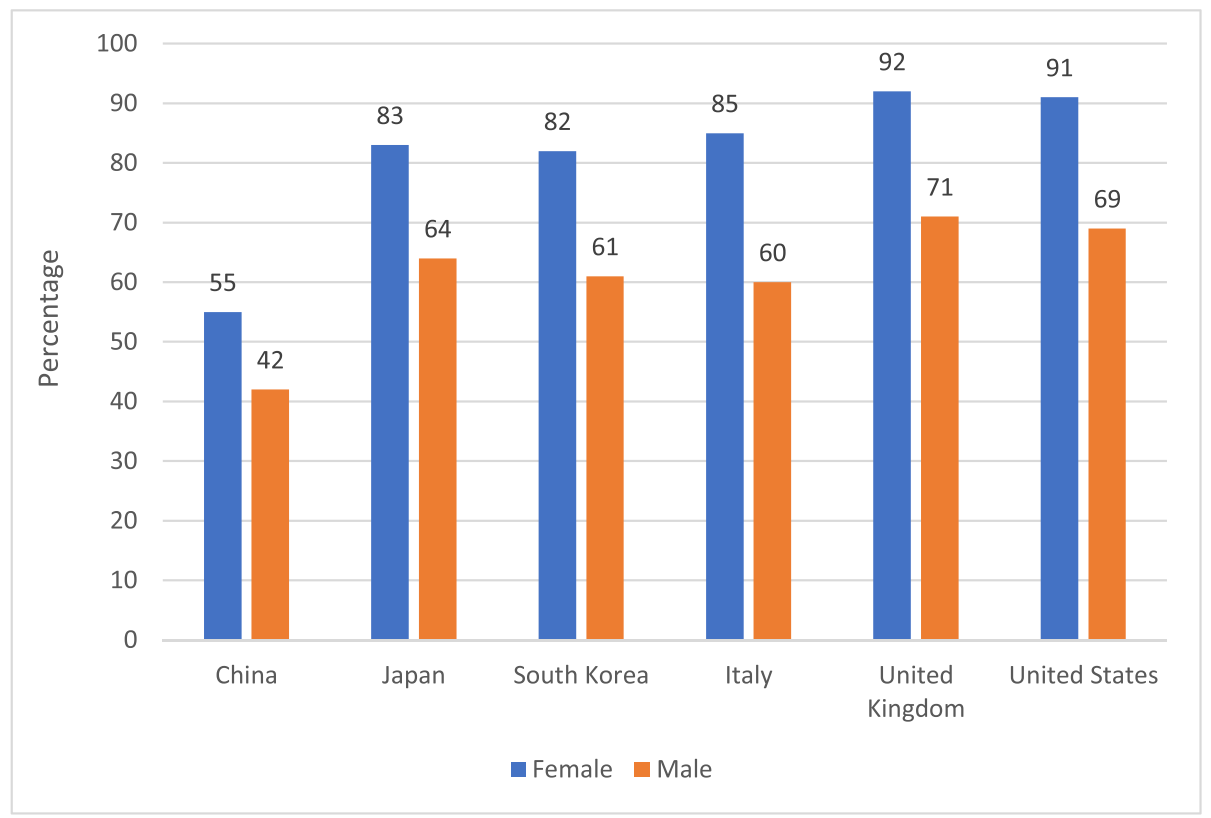

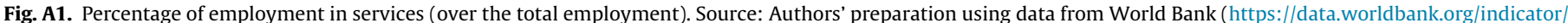
SL.TLF.CACT.MA.NE.ZS). 


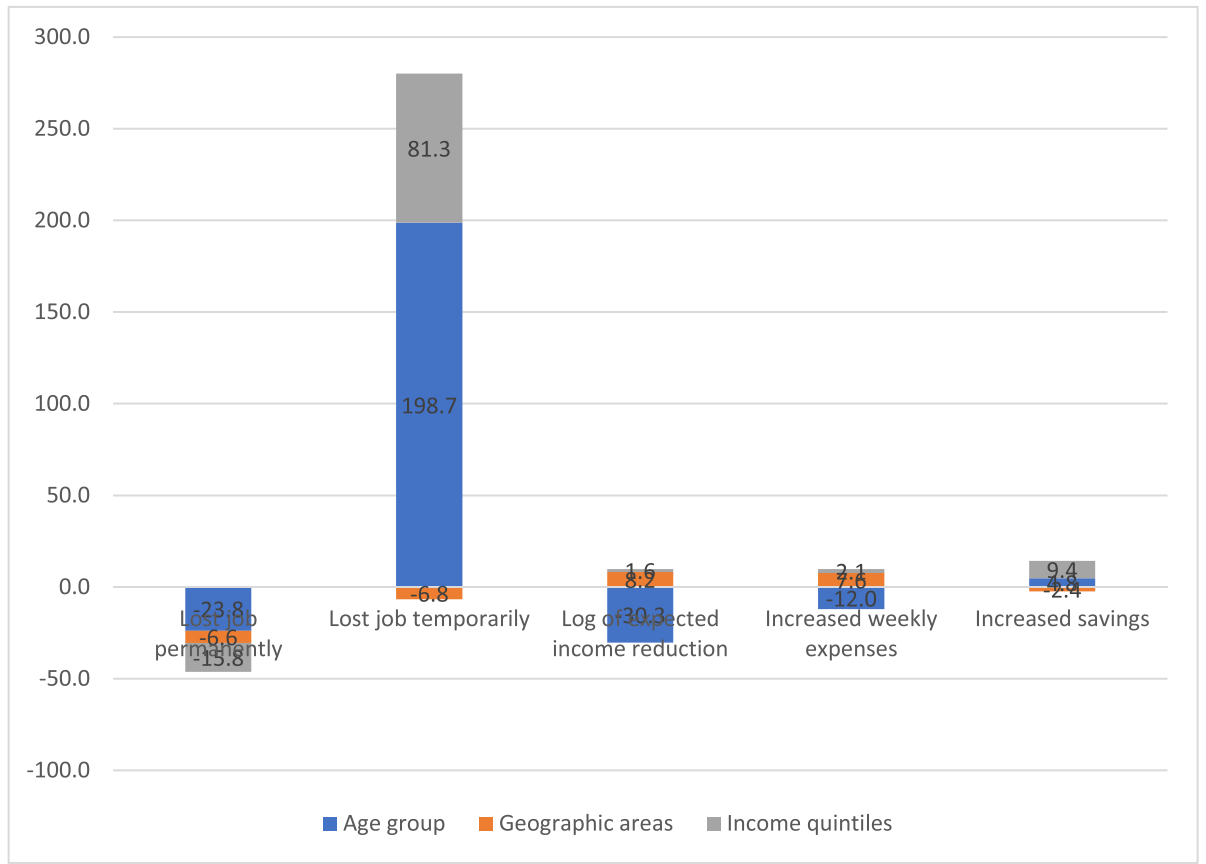

Fig. A2. Contribution of explained components to the total gender difference.

Table A1

Gender and age of respondents.

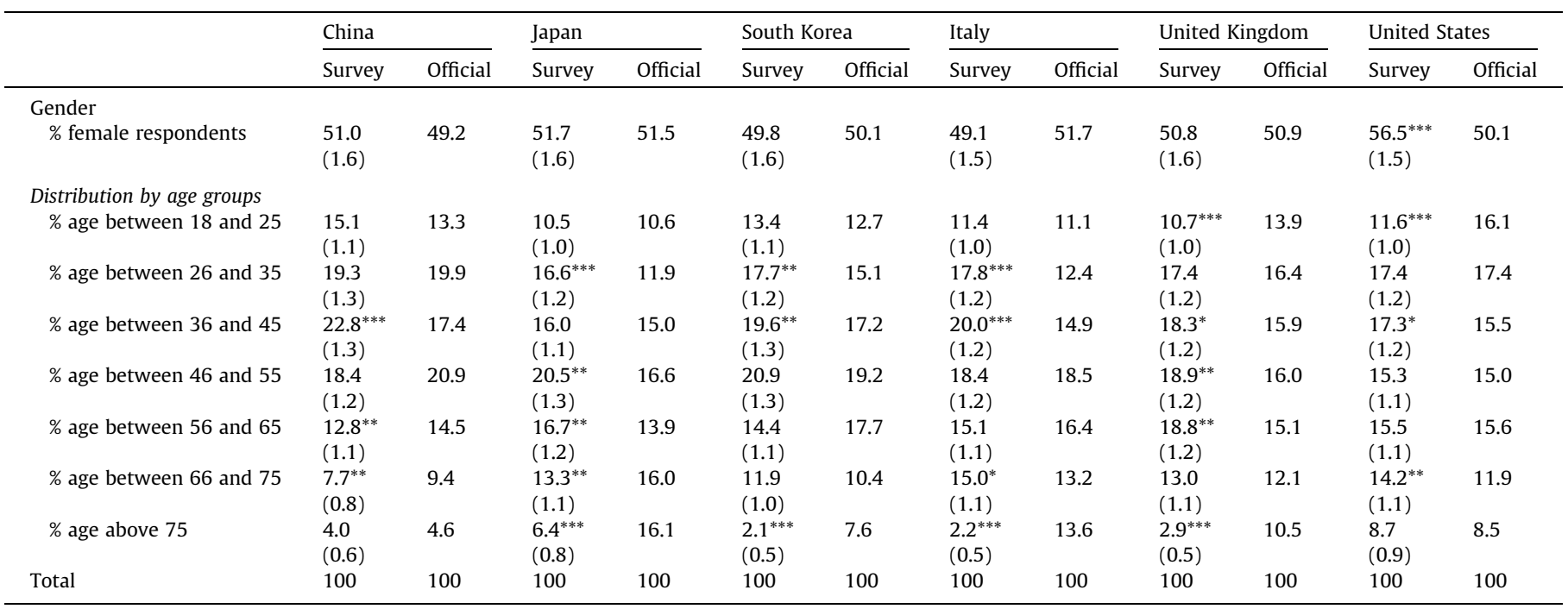

Note: This table compares the proportion of respondents by gender and age of respondents, which are estimated by the COVID-19 survey, and the official number which are obtained from https://www.populationpyramid.net/. The standard error of the estimates from the COVID-19 survey is reported in parentheses. We assume that there are no standard errors associated with the official estimates.

${ }^{* * *} \mathrm{p}<0.01,{ }^{* *} \mathrm{p}<0.05,{ }^{*} \mathrm{p}<0.1$ : denote the significance level of the Z-test of equality of the proportion between the CovID-19 estimates and the official ones.

Table A2

Income quintiles of respondents.

\begin{tabular}{|c|c|c|c|c|c|c|}
\hline Income quintiles & China & Japan & South Korea & Italy & United Kingdom & United States \\
\hline First quintile & $\begin{array}{l}20.2 \\
(1.3)\end{array}$ & $\begin{array}{l}21.1 \\
(1.3)\end{array}$ & $\begin{array}{l}21.5 \\
(1.4)\end{array}$ & $\begin{array}{l}16.7^{* * * *} \\
(1.2)\end{array}$ & $\begin{array}{l}18.1^{*} \\
(1.2)\end{array}$ & $\begin{array}{l}17.4^{* *} \\
(1.2)\end{array}$ \\
\hline Second quintile & $\begin{array}{l}20.0 \\
(1.3)\end{array}$ & $\begin{array}{l}21.3 \\
(1.3)\end{array}$ & $\begin{array}{l}17.7^{*} \\
(1.3)\end{array}$ & $\begin{array}{l}17.5^{* *} \\
(1.2)\end{array}$ & $\begin{array}{l}18.1^{*} \\
(1.2)\end{array}$ & $\begin{array}{l}18.9 \\
(1.2)\end{array}$ \\
\hline Third quintile & $\begin{array}{l}19.9 \\
(1.3)\end{array}$ & $\begin{array}{l}21.8 \\
(1.3)\end{array}$ & $\begin{array}{l}21.7 \\
(1.4)\end{array}$ & $\begin{array}{l}23.9^{* *} \\
(1.3)\end{array}$ & $\begin{array}{l}19.7 \\
(1.3)\end{array}$ & $\begin{array}{l}21.0 \\
(1.3)\end{array}$ \\
\hline
\end{tabular}


Table A2 (continued)

\begin{tabular}{|c|c|c|c|c|c|c|}
\hline Income quintiles & China & Japan & South Korea & Italy & United Kingdom & United States \\
\hline Fourth quintile & $\begin{array}{l}19.9 \\
(1.3)\end{array}$ & $\begin{array}{l}19.0 \\
(1.3)\end{array}$ & $\begin{array}{l}21.8 \\
(1.4)\end{array}$ & $\begin{array}{l}25.8^{* * *} \\
(1.4)\end{array}$ & $\begin{array}{l}22.3^{*} \\
(1.3)\end{array}$ & $\begin{array}{l}23.6^{* * * *} \\
(1.3)\end{array}$ \\
\hline Fifth quintile & $\begin{array}{l}19.9 \\
(1.3)\end{array}$ & $\begin{array}{l}16.8^{*} \\
(1.2)\end{array}$ & $\begin{array}{l}17.3^{* *} \\
(1.2)\end{array}$ & $\begin{array}{l}16.2^{* * *} \\
(1.2)\end{array}$ & $\begin{array}{l}21.8 \\
(1.3)\end{array}$ & $\begin{array}{l}19.2 \\
(1.2)\end{array}$ \\
\hline Total & 100 & 100 & 100 & 100 & 100 & 100 \\
\hline
\end{tabular}

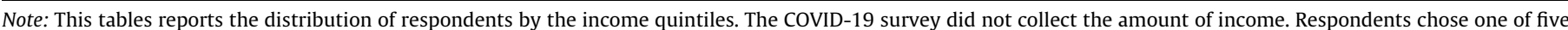

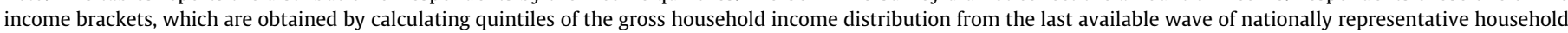

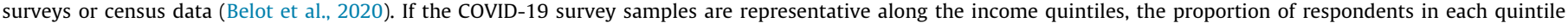
should be $20 \%$.

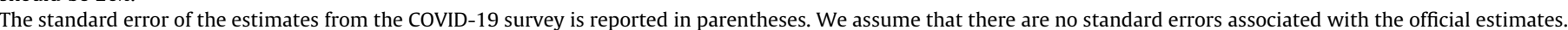
${ }^{* * *} \mathrm{p}<0.01,{ }^{* *} \mathrm{p}<0.05,{ }^{*} \mathrm{p}<0.1$ : denote the significance level of the Z-test of equality of the proportion between the COVID-19 estimates and $20 \%$.

Table A3

Gender differences in the outcome variables by countries.

\begin{tabular}{|c|c|c|c|c|}
\hline Countries & Outcomes & Female & Male & Difference \\
\hline \multirow[t]{5}{*}{ China } & $\%$ people losing job permanently & $4.9^{* * *}$ & $2.0^{* * *}$ & $2.9^{* *}$ \\
\hline & $\%$ people losing job temporarily & $40.8^{* * *}$ & $38.8^{* * *}$ & 2.0 \\
\hline & Log of expected income reduction & $3.361^{* * *}$ & $3.547^{* * *}$ & -0.186 \\
\hline & Increased weekly expenses & $2.484^{* * *}$ & $2.354^{* * *}$ & $0.130^{*}$ \\
\hline & Increased savings & $2.350^{* * *}$ & $2.248^{* * *}$ & 0.102 \\
\hline \multirow[t]{5}{*}{ Japan } & $\%$ people losing job permanently & $1.8^{* * *}$ & $4.4^{* * *}$ & $-2.5^{* *}$ \\
\hline & $\%$ people losing job temporarily & $10.5^{* * *}$ & $12.1^{* * *}$ & -1.7 \\
\hline & Log of expected income reduction & $5.211^{* * *}$ & $4.552^{* * *}$ & $0.659^{*}$ \\
\hline & Increased weekly expenses & $2.781^{* * *}$ & $2.816^{* * *}$ & -0.035 \\
\hline & Increased savings & $2.547^{* * *}$ & $2.639^{* * *}$ & $-0.092^{*}$ \\
\hline \multirow[t]{5}{*}{ South Korea } & $\%$ people losing job permanently & $3.1^{* * *}$ & $4.4^{* * *}$ & -1.3 \\
\hline & $\%$ people losing job temporarily & $20.9^{* * *}$ & $21.7^{* * *}$ & -0.8 \\
\hline & Log of expected income reduction & $5.870^{* * *}$ & $5.708^{* * *}$ & 0.162 \\
\hline & Increased weekly expenses & $2.410^{* * *}$ & $2.446^{* * *}$ & -0.036 \\
\hline & Increased savings & $2.511^{* * *}$ & $2.377^{* * *}$ & $0.134^{* *}$ \\
\hline \multirow[t]{5}{*}{ Italy } & $\%$ people losing job permanently & $9.2^{* * *}$ & $7.2^{* * *}$ & 2.0 \\
\hline & $\%$ people losing job temporarily & $26.7^{* * *}$ & $30.6^{* * *}$ & -3.9 \\
\hline & Log of expected income reduction & $3.675^{* * *}$ & $4.010^{* * *}$ & -0.335 \\
\hline & Increased weekly expenses & $2.288^{* * *}$ & $2.302^{* * *}$ & -0.014 \\
\hline & Increased savings & $2.493^{* * *}$ & $2.288^{* * *}$ & $0.205^{* * *}$ \\
\hline \multirow[t]{5}{*}{ United Kingdom } & $\%$ people losing job permanently & $5.0^{* * *}$ & $5.4^{* * *}$ & -0.4 \\
\hline & $\%$ people losing job temporarily & $24.6^{* * *}$ & $22.2^{* * *}$ & 2.4 \\
\hline & Log of expected income reduction & $3.042^{* * *}$ & $2.541^{* * *}$ & $0.501^{* *}$ \\
\hline & Increased weekly expenses & $2.473^{* * *}$ & $2.679^{* * *}$ & $-0.206^{* * *}$ \\
\hline & Increased savings & $2.677^{* * *}$ & $2.679^{* * *}$ & -0.002 \\
\hline \multirow[t]{5}{*}{ United States } & $\%$ people losing job permanently & $10.9^{* * *}$ & $6.0^{* * *}$ & $4.9^{* * *}$ \\
\hline & $\%$ people losing job temporarily & $23.6^{* * *}$ & $24.6^{* * *}$ & -1.0 \\
\hline & Log of expected income reduction & $3.934^{* * *}$ & $2.720^{* * *}$ & $1.214^{* * *}$ \\
\hline & Increased weekly expenses & $2.504^{* * *}$ & $2.668^{* * *}$ & $-0.164^{* *}$ \\
\hline & Increased savings & $2.568^{* * *}$ & $2.528^{* * *}$ & 0.04 \\
\hline
\end{tabular}

Standard errors in parentheses.

${ }^{* * *} \mathrm{p}<0.01,{ }^{* *} \mathrm{p}<0.05,{ }^{*} \mathrm{p}<0.1$ : denote the statistical levels of difference from zero.

Table A4

Regressions of outcome variables using Model 4.

\begin{tabular}{|c|c|c|c|c|c|}
\hline Explanatory variables & Lost job permanently & Lost job temporarily & Log of expected income reduction & Increased weekly expenses & Increased savings \\
\hline Female $($ female $=1$, others $=0$ ) & $\begin{array}{l}0.013^{* *} \\
(0.006)\end{array}$ & $\begin{array}{l}0.007 \\
(0.011)\end{array}$ & $\begin{array}{l}0.448^{* * *} \\
(0.129)\end{array}$ & $\begin{array}{l}-0.065^{* *} \\
(0.030)\end{array}$ & $\begin{array}{l}0.053^{*} \\
(0.027)\end{array}$ \\
\hline Age group (18 to 25 ) & Reference & & & & \\
\hline Age group (26 to 35 ) & $\begin{array}{l}0.006 \\
(0.013)\end{array}$ & $\begin{array}{c}-0.008 \\
(0.022)\end{array}$ & $\begin{array}{l}0.118 \\
(0.246)\end{array}$ & $\begin{array}{l}0.014 \\
(0.059)\end{array}$ & $\begin{array}{l}-0.123^{* *} \\
(0.056)\end{array}$ \\
\hline Age group (36 to 45 ) & $\begin{array}{l}-0.011 \\
(0.012)\end{array}$ & $\begin{array}{l}0.018 \\
(0.022)\end{array}$ & $\begin{array}{l}0.203 \\
(0.241)\end{array}$ & $\begin{array}{l}0.089 \\
(0.060)\end{array}$ & $\begin{array}{l}-0.220^{* * *} \\
(0.054)\end{array}$ \\
\hline Age group (46 to 55 ) & $\begin{array}{l}-0.034^{* * *} \\
(0.012)\end{array}$ & $\begin{array}{l}0.008 \\
(0.022)\end{array}$ & $\begin{array}{l}0.136 \\
(0.245)\end{array}$ & $\begin{array}{l}0.038 \\
(0.058)\end{array}$ & $\begin{array}{l}-0.248^{* * *} \\
(0.054)\end{array}$ \\
\hline Age group (56 to 65 ) & $\begin{array}{l}-0.051^{\text {**** }} \\
(0.012)\end{array}$ & $\begin{array}{l}-0.061^{* * *} \\
(0.022)\end{array}$ & $\begin{array}{l}-0.572^{* *} \\
(0.251)\end{array}$ & $\begin{array}{l}0.035 \\
(0.058)\end{array}$ & $\begin{array}{l}-0.141^{* *} \\
(0.055)\end{array}$ \\
\hline Age group (66 to 75 ) & $\begin{array}{l}-0.068^{* * *} \\
(0.011)\end{array}$ & $\begin{array}{l}-0.166^{* * *} \\
(0.021)\end{array}$ & $\begin{array}{l}-2.372^{* * *} \\
(0.246)\end{array}$ & $\begin{array}{l}0.194^{* * *} \\
(0.062)\end{array}$ & $\begin{array}{l}0.094 \\
(0.058)\end{array}$ \\
\hline Age group (Above 76) & $\begin{array}{l}-0.055^{* * *} \\
(0.014)\end{array}$ & $\begin{array}{l}-0.181^{* * *} \\
(0.025)\end{array}$ & $\begin{array}{l}-2.913^{* * *} \\
(0.305)\end{array}$ & $\begin{array}{l}0.129 * \\
(0.077)\end{array}$ & $\begin{array}{l}0.045 \\
(0.072)\end{array}$ \\
\hline Living alone & $\begin{array}{l}0.015^{*} \\
(0.008)\end{array}$ & $\begin{array}{l}-0.015 \\
(0.013)\end{array}$ & $\begin{array}{l}-0.096 \\
(0.152)\end{array}$ & $\begin{array}{l}0.005 \\
(0.036)\end{array}$ & $\begin{array}{l}0.043 \\
(0.033)\end{array}$ \\
\hline
\end{tabular}


Table A4 (continued)

\begin{tabular}{|c|c|c|c|c|c|}
\hline Explanatory variables & Lost job permanently & Lost job temporarily & Log of expected income reduction & Increased weekly expenses & Increased savings \\
\hline Urban & $\begin{array}{l}0.025^{* * *} \\
(0.009)\end{array}$ & $\begin{array}{l}0.016 \\
(0.017)\end{array}$ & $\begin{array}{l}0.288 \\
(0.206)\end{array}$ & $\begin{array}{c}-0.014 \\
(0.049)\end{array}$ & $\begin{array}{c}-0.044 \\
(0.046)\end{array}$ \\
\hline Sub-urban & $\begin{array}{l}0.005 \\
(0.008)\end{array}$ & $\begin{array}{l}0.030^{*} \\
(0.016)\end{array}$ & $\begin{array}{l}-0.105 \\
(0.201)\end{array}$ & $\begin{array}{r}-0.002 \\
(0.047)\end{array}$ & $\begin{array}{l}0.051 \\
(0.043)\end{array}$ \\
\hline Poorest quintile & $\begin{array}{l}0.034^{* * *} \\
(0.011)\end{array}$ & $\begin{array}{l}0.098^{* * *} \\
(0.018)\end{array}$ & $\begin{array}{l}-0.051 \\
(0.213)\end{array}$ & $\begin{array}{l}0.004 \\
(0.052)\end{array}$ & $\begin{array}{l}-0.147^{* * *} \\
(0.046)\end{array}$ \\
\hline Second poorest quintile & $\begin{array}{l}0.014 \\
(0.010)\end{array}$ & $\begin{array}{l}0.108^{* * *} \\
(0.018)\end{array}$ & $\begin{array}{l}0.769^{* * * *} \\
(0.213)\end{array}$ & $\begin{array}{c}-0.044 \\
(0.051)\end{array}$ & $\begin{array}{l}-0.203^{* * *} \\
(0.045)\end{array}$ \\
\hline Middle quintile & $\begin{array}{l}-0.001 \\
(0.009)\end{array}$ & $\begin{array}{l}0.087^{* * *} \\
(0.017)\end{array}$ & $\begin{array}{l}0.388^{*} \\
(0.207)\end{array}$ & $\begin{array}{l}-0.056 \\
(0.049)\end{array}$ & $\begin{array}{l}-0.173^{* * *} \\
(0.044)\end{array}$ \\
\hline Second richest quintile & $\begin{array}{l}-0.010 \\
(0.008)\end{array}$ & $\begin{array}{l}0.053^{* * *} \\
(0.016)\end{array}$ & $\begin{array}{l}0.438^{* *} \\
(0.203)\end{array}$ & $\begin{array}{l}-0.086^{*} \\
(0.048)\end{array}$ & $\begin{array}{l}-0.041 \\
(0.042)\end{array}$ \\
\hline Richest quintile & Reference & & & & \\
\hline Country fixed-effects & Yes & Yes & Yes & Yes & Yes \\
\hline Regions fixed-effects & Yes & Yes & Yes & Yes & Yes \\
\hline Constant & $\begin{array}{l}0.049 * * * \\
(0.013)\end{array}$ & $\begin{array}{l}0.196^{* * *} \\
(0.025)\end{array}$ & $\begin{array}{l}3.807^{* * *} \\
(0.291)\end{array}$ & $\begin{array}{l}2.533^{* * *} \\
(0.070)\end{array}$ & $\begin{array}{l}2.687^{* * *} \\
(0.065)\end{array}$ \\
\hline Observations & 6,089 & 6,089 & 6,089 & 6,089 & 6,089 \\
\hline R-squared & 0.043 & 0.083 & 0.100 & 0.043 & 0.050 \\
\hline
\end{tabular}

Robust standard errors in parentheses.

${ }^{* * *} \mathrm{p}<0.01,{ }^{* *} \mathrm{p}<0.05,{ }^{*} \mathrm{p}<0.1$

Table A5

Regressions of outcome variables using the large specification model and controlling for employment industry.

\begin{tabular}{|c|c|c|c|c|c|}
\hline Explanatory variables & $\begin{array}{l}\text { Lost job } \\
\text { permanently }\end{array}$ & $\begin{array}{l}\text { Lost job } \\
\text { temporarily }\end{array}$ & Log of expected income reduction & $\begin{array}{l}\text { Increased weekly } \\
\text { expenses }\end{array}$ & $\begin{array}{l}\text { Increased } \\
\text { savings }\end{array}$ \\
\hline Female $($ female $=1$, others $=0$ ) & $\begin{array}{l}0.013^{* *} \\
(0.006)\end{array}$ & $\begin{array}{l}-0.019 * \\
(0.011)\end{array}$ & $\begin{array}{l}0.045 \\
(0.127)\end{array}$ & $\begin{array}{l}-0.029 \\
(0.031)\end{array}$ & $\begin{array}{l}0.084^{* * *} \\
(0.028)\end{array}$ \\
\hline Age group (18 to 25 ) & Reference & & & & \\
\hline Age group (26 to 35 ) & $\begin{array}{l}0.008 \\
(0.013)\end{array}$ & $\begin{array}{l}-0.032 \\
(0.022)\end{array}$ & $\begin{array}{l}-0.267 \\
(0.247)\end{array}$ & $\begin{array}{l}0.058 \\
(0.060)\end{array}$ & $\begin{array}{l}-0.119^{* *} \\
(0.057)\end{array}$ \\
\hline Age group (36 to 45 ) & $\begin{array}{l}-0.010 \\
(0.013)\end{array}$ & $\begin{array}{l}-0.010 \\
(0.021)\end{array}$ & $\begin{array}{l}-0.208 \\
(0.241)\end{array}$ & $\begin{array}{l}0.140^{* *} \\
(0.060)\end{array}$ & $\begin{array}{l}-0.208^{* * *} \\
(0.055)\end{array}$ \\
\hline Age group (46 to 55 ) & $\begin{array}{l}-0.032^{* * *} \\
(0.012)\end{array}$ & $\begin{array}{l}-0.013 \\
(0.021)\end{array}$ & $\begin{array}{l}-0.132 \\
(0.244)\end{array}$ & $\begin{array}{l}0.078 \\
(0.059)\end{array}$ & $\begin{array}{l}-0.246^{* * *} \\
(0.054)\end{array}$ \\
\hline Age group (56 to 65 ) & $\begin{array}{l}-0.049^{* * *} \\
(0.012)\end{array}$ & $\begin{array}{l}-0.045^{* *} \\
(0.021)\end{array}$ & $\begin{array}{l}-0.410^{*} \\
(0.247)\end{array}$ & $\begin{array}{l}0.041 \\
(0.059)\end{array}$ & $\begin{array}{l}-0.153^{* * *} \\
(0.056)\end{array}$ \\
\hline Age group (66 to 75 ) & $\begin{array}{l}-0.067^{* * *} \\
(0.012)\end{array}$ & $\begin{array}{l}-0.084^{* * *} \\
(0.021)\end{array}$ & $\begin{array}{l}-1.314^{* * *} \\
(0.253)\end{array}$ & $\begin{array}{l}0.113^{*} \\
(0.064)\end{array}$ & $\begin{array}{l}0.049 \\
(0.060)\end{array}$ \\
\hline Age group (Above 76) & $\begin{array}{l}-0.053^{* * *} \\
(0.014)\end{array}$ & $\begin{array}{l}-0.065^{* * *} \\
(0.025)\end{array}$ & $\begin{array}{l}-1.445^{* * *} \\
(0.302)\end{array}$ & $\begin{array}{l}0.013 \\
(0.080)\end{array}$ & $\begin{array}{l}-0.019 \\
(0.075)\end{array}$ \\
\hline Living alone & $\begin{array}{l}0.014^{*} \\
(0.008)\end{array}$ & $\begin{array}{l}-0.024^{*} \\
(0.013)\end{array}$ & $\begin{array}{l}-0.204 \\
(0.148)\end{array}$ & $\begin{array}{l}0.016 \\
(0.036)\end{array}$ & $\begin{array}{l}0.047 \\
(0.033)\end{array}$ \\
\hline Urban & $\begin{array}{l}0.027^{* * * *} \\
(0.009)\end{array}$ & $\begin{array}{l}0.007 \\
(0.016)\end{array}$ & $\begin{array}{l}0.106 \\
(0.197)\end{array}$ & $\begin{array}{l}-0.002 \\
(0.050)\end{array}$ & $\begin{array}{l}-0.048 \\
(0.046)\end{array}$ \\
\hline Sub-urban & $\begin{array}{l}0.006 \\
(0.008)\end{array}$ & $\begin{array}{l}0.025 \\
(0.015)\end{array}$ & $\begin{array}{l}-0.182 \\
(0.190)\end{array}$ & $\begin{array}{l}-0.002 \\
(0.047)\end{array}$ & $\begin{array}{l}0.046 \\
(0.044)\end{array}$ \\
\hline Poorest quintile & $\begin{array}{l}0.028^{* *} \\
(0.011)\end{array}$ & $\begin{array}{l}0.126^{* * *} \\
(0.018)\end{array}$ & $\begin{array}{l}0.516^{* *} \\
(0.212)\end{array}$ & $\begin{array}{l}-0.070 \\
(0.054)\end{array}$ & $\begin{array}{l}-0.143^{* * *} \\
(0.048)\end{array}$ \\
\hline Second poorest quintile & $\begin{array}{l}0.011 \\
(0.010)\end{array}$ & $\begin{array}{l}0.099 * * * \\
(0.018)\end{array}$ & $\begin{array}{l}0.837^{* * *} \\
(0.208)\end{array}$ & $\begin{array}{l}-0.065 \\
(0.051)\end{array}$ & $\begin{array}{l}-0.189^{* * *} \\
(0.045)\end{array}$ \\
\hline Middle quintile & $\begin{array}{l}-0.003 \\
(0.009)\end{array}$ & $\begin{array}{l}0.067^{* * *} \\
(0.017)\end{array}$ & $\begin{array}{l}0.295 \\
(0.202)\end{array}$ & $\begin{array}{l}-0.062 \\
(0.050)\end{array}$ & $\begin{array}{l}-0.156^{* * *} \\
(0.044)\end{array}$ \\
\hline Second richest quintile & $\begin{array}{l}-0.011 \\
(0.008)\end{array}$ & $\begin{array}{l}0.032^{* *} \\
(0.016)\end{array}$ & $\begin{array}{l}0.305 \\
(0.198)\end{array}$ & $\begin{array}{l}-0.077 \\
(0.048)\end{array}$ & $\begin{array}{l}-0.029 \\
(0.042)\end{array}$ \\
\hline Richest quintile & Reference & & & & \\
\hline Country fixed-effects & Yes & Yes & Yes & Yes & Yes \\
\hline Regions fixed-effects & Yes & Yes & Yes & Yes & Yes \\
\hline $\begin{array}{l}\text { Employment industry fixed- } \\
\text { effects }\end{array}$ & Yes & Yes & Yes & Yes & Yes \\
\hline Constant & $\begin{array}{l}0.076^{* * * *} \\
(0.023)\end{array}$ & $\begin{array}{l}0.479^{* * *} \\
(0.040)\end{array}$ & $\begin{array}{l}6.329^{* * * *} \\
(0.429)\end{array}$ & $\begin{array}{l}2.550^{* * * *} \\
(0.113)\end{array}$ & $\begin{array}{l}2.470^{* * *} \\
(0.103)\end{array}$ \\
\hline Observations & 6,089 & 6,089 & 6,089 & 6,089 & 6,089 \\
\hline R-squared & 0.050 & 0.148 & 0.163 & 0.051 & 0.061 \\
\hline
\end{tabular}

Robust standard errors in parentheses.

${ }^{* * *} \mathrm{p}<0.01,{ }^{* *} \mathrm{p}<0.05,{ }^{*} \mathrm{p}<0.1$ 
Table A6

OLS regression for female and male samples.

\begin{tabular}{|c|c|c|c|c|c|c|c|c|}
\hline \multirow[t]{2}{*}{ Explanatory variables } & \multicolumn{2}{|c|}{ Lost job permanently } & \multicolumn{2}{|c|}{$\begin{array}{l}\text { Log of expected income } \\
\text { reduction }\end{array}$} & \multicolumn{2}{|c|}{$\begin{array}{l}\text { Increased weekly } \\
\text { expenses }\end{array}$} & \multicolumn{2}{|c|}{ Increased savings } \\
\hline & Female & Male & Female & Male & Female & Male & Female & Male \\
\hline Age group (18 to 25 ) & Reference & & & & & & & \\
\hline Age group (26 to 35 ) & $\begin{array}{l}0.044^{* *} \\
(0.020)\end{array}$ & $\begin{array}{l}-0.015 \\
(0.017)\end{array}$ & $\begin{array}{l}-0.132 \\
(0.381)\end{array}$ & $\begin{array}{l}0.390 \\
(0.325)\end{array}$ & $\begin{array}{l}0.032 \\
(0.092)\end{array}$ & $\begin{array}{l}-0.021 \\
(0.078)\end{array}$ & $\begin{array}{l}-0.139 \\
(0.089)\end{array}$ & $\begin{array}{l}-0.093 \\
(0.073)\end{array}$ \\
\hline Age group (36 to 45 ) & $\begin{array}{l}0.024 \\
(0.019)\end{array}$ & $\begin{array}{l}-0.035^{* *} \\
(0.016)\end{array}$ & $\begin{array}{l}0.653^{*} \\
(0.374)\end{array}$ & $\begin{array}{l}-0.333 \\
(0.325)\end{array}$ & $\begin{array}{l}0.010 \\
(0.088)\end{array}$ & $\begin{array}{l}0.152^{*} \\
(0.082)\end{array}$ & $\begin{array}{l}-0.237^{* * *} \\
(0.085)\end{array}$ & $\begin{array}{l}-0.191^{* * *} \\
(0.072)\end{array}$ \\
\hline Age group (46 to 55 ) & $\begin{array}{l}-0.010 \\
(0.017)\end{array}$ & $\begin{array}{l}-0.042^{* * *} \\
(0.016)\end{array}$ & $\begin{array}{l}0.287 \\
(0.384)\end{array}$ & $\begin{array}{l}0.086 \\
(0.324)\end{array}$ & $\begin{array}{l}-0.088 \\
(0.088)\end{array}$ & $\begin{array}{l}0.135^{*} \\
(0.079)\end{array}$ & $\begin{array}{l}-0.229^{* * *} \\
(0.085)\end{array}$ & $\begin{array}{l}-0.260^{* * *} \\
(0.070)\end{array}$ \\
\hline Age group (56 to 65 ) & $\begin{array}{l}-0.033^{* *} \\
(0.016)\end{array}$ & $\begin{array}{l}-0.053^{* * *} \\
(0.016)\end{array}$ & $\begin{array}{l}-0.456 \\
(0.392)\end{array}$ & $\begin{array}{l}-0.700^{* *} \\
(0.334)\end{array}$ & $\begin{array}{l}-0.042 \\
(0.086)\end{array}$ & $\begin{array}{l}0.103 \\
(0.081)\end{array}$ & $\begin{array}{l}-0.150^{*} \\
(0.086)\end{array}$ & $\begin{array}{l}-0.119 \\
(0.073)\end{array}$ \\
\hline Age group (66 to 75 ) & $\begin{array}{l}-0.037^{* *} \\
(0.017)\end{array}$ & $\begin{array}{l}-0.087^{* * *} \\
(0.015)\end{array}$ & $\begin{array}{l}-2.347^{* * *} \\
(0.384)\end{array}$ & $\begin{array}{l}-2.356^{* * *} \\
(0.323)\end{array}$ & $\begin{array}{l}0.089 \\
(0.091)\end{array}$ & $\begin{array}{l}0.284^{* * *} \\
(0.085)\end{array}$ & $\begin{array}{l}0.190^{* *} \\
(0.091)\end{array}$ & $\begin{array}{c}-0.003 \\
(0.078)\end{array}$ \\
\hline Age group (Above 76) & $\begin{array}{l}-0.018 \\
(0.021)\end{array}$ & $\begin{array}{l}-0.098^{* * *} \\
(0.015)\end{array}$ & $\begin{array}{l}-3.262^{\text {**** }} \\
(0.432)\end{array}$ & $\begin{array}{l}-2.296^{* * *} \\
(0.460)\end{array}$ & $\begin{array}{l}0.052 \\
(0.104)\end{array}$ & $\begin{array}{l}0.192 \\
(0.125)\end{array}$ & $\begin{array}{l}0.138 \\
(0.101)\end{array}$ & $\begin{array}{c}-0.016 \\
(0.110)\end{array}$ \\
\hline Living alone & $\begin{array}{l}0.002 \\
(0.011)\end{array}$ & $\begin{array}{l}0.027^{* *} \\
(0.011)\end{array}$ & $\begin{array}{l}-0.193 \\
(0.218)\end{array}$ & $\begin{array}{l}0.093 \\
(0.217)\end{array}$ & $\begin{array}{l}0.009 \\
(0.050)\end{array}$ & $\begin{array}{c}-0.014 \\
(0.053)\end{array}$ & $\begin{array}{l}0.072 \\
(0.047)\end{array}$ & $\begin{array}{l}0.026 \\
(0.046)\end{array}$ \\
\hline Urban & $\begin{array}{l}0.030^{* *} \\
(0.013)\end{array}$ & $\begin{array}{l}0.018 \\
(0.013)\end{array}$ & $\begin{array}{l}0.374 \\
(0.310)\end{array}$ & $\begin{array}{l}0.206 \\
(0.277)\end{array}$ & $\begin{array}{l}0.013 \\
(0.068)\end{array}$ & $\begin{array}{c}-0.029 \\
(0.072)\end{array}$ & $\begin{array}{c}-0.048 \\
(0.064)\end{array}$ & $\begin{array}{c}-0.062 \\
(0.064)\end{array}$ \\
\hline Sub-urban & $\begin{array}{l}0.003 \\
(0.012)\end{array}$ & $\begin{array}{l}0.007 \\
(0.011)\end{array}$ & $\begin{array}{c}-0.082 \\
(0.310)\end{array}$ & $\begin{array}{r}-0.088 \\
(0.267)\end{array}$ & $\begin{array}{l}0.014 \\
(0.066)\end{array}$ & $\begin{array}{r}-0.015 \\
(0.068)\end{array}$ & $\begin{array}{l}0.015 \\
(0.061)\end{array}$ & $\begin{array}{l}0.058 \\
(0.061)\end{array}$ \\
\hline Income quantile 1 & $\begin{array}{l}0.058^{* * *} \\
(0.016)\end{array}$ & $\begin{array}{l}0.018 \\
(0.014)\end{array}$ & $\begin{array}{l}0.008 \\
(0.324)\end{array}$ & $\begin{array}{l}-0.164 \\
(0.292)\end{array}$ & $\begin{array}{l}0.024 \\
(0.076)\end{array}$ & $\begin{array}{c}-0.033 \\
(0.072)\end{array}$ & $\begin{array}{l}-0.135^{*} \\
(0.070)\end{array}$ & $\begin{array}{l}-0.142^{* *} \\
(0.061)\end{array}$ \\
\hline Income quantile 2 & $\begin{array}{l}0.024^{*} \\
(0.014)\end{array}$ & $\begin{array}{l}0.007 \\
(0.014)\end{array}$ & $\begin{array}{l}0.509^{*} \\
(0.308)\end{array}$ & $\begin{array}{l}0.954^{* * * *} \\
(0.300)\end{array}$ & $\begin{array}{l}0.030 \\
(0.072)\end{array}$ & $\begin{array}{l}-0.103 \\
(0.073)\end{array}$ & $\begin{array}{l}-0.192^{* * *} \\
(0.067)\end{array}$ & $\begin{array}{l}-0.210^{* * *} \\
(0.062)\end{array}$ \\
\hline Income quantile 3 & $\begin{array}{l}0.002 \\
(0.013)\end{array}$ & $\begin{array}{l}-0.002 \\
(0.012)\end{array}$ & $\begin{array}{l}0.458 \\
(0.303)\end{array}$ & $\begin{array}{l}0.285 \\
(0.286)\end{array}$ & $\begin{array}{c}-0.019 \\
(0.069)\end{array}$ & $\begin{array}{l}-0.089 \\
(0.071)\end{array}$ & $\begin{array}{l}-0.197^{* * *} \\
(0.063)\end{array}$ & $\begin{array}{l}-0.139^{* *} \\
(0.061)\end{array}$ \\
\hline Income quantile 4 & $\begin{array}{l}-0.012 \\
(0.012)\end{array}$ & $\begin{array}{c}-0.001 \\
(0.012)\end{array}$ & $\begin{array}{l}0.633^{* *} \\
(0.289)\end{array}$ & $\begin{array}{l}0.245 \\
(0.287)\end{array}$ & $\begin{array}{c}-0.039 \\
(0.066)\end{array}$ & $\begin{array}{l}-0.125^{*} \\
(0.069)\end{array}$ & $\begin{array}{l}-0.051 \\
(0.061)\end{array}$ & $\begin{array}{l}-0.019 \\
(0.060)\end{array}$ \\
\hline Income quantile 5 & Reference & & & & & & & \\
\hline Country fixed-effects & Yes & Yes & Yes & Yes & Yes & Yes & Yes & Yes \\
\hline Region fixed-effects & Yes & Yes & Yes & Yes & Yes & Yes & Yes & Yes \\
\hline Constant & $\begin{array}{l}0.030 \\
(0.019)\end{array}$ & $\begin{array}{l}0.067^{* * * *} \\
(0.018)\end{array}$ & $\begin{array}{l}4.134^{* * *} \\
(0.447)\end{array}$ & $\begin{array}{l}3.895^{\text {*** }} \\
(0.378)\end{array}$ & $\begin{array}{l}2.477^{* * *} \\
(0.101)\end{array}$ & $\begin{array}{l}2.538^{* * *} \\
(0.095)\end{array}$ & $\begin{array}{l}2.738^{* * *} \\
(0.097)\end{array}$ & $\begin{array}{l}2.685^{* * *} \\
(0.086)\end{array}$ \\
\hline Observations & 2,947 & 3,142 & 2,947 & 3,142 & 2,947 & 3,142 & 2,947 & 3,142 \\
\hline R-squared & 0.082 & 0.054 & 0.126 & 0.111 & 0.065 & 0.061 & 0.069 & 0.067 \\
\hline
\end{tabular}

Robust standard errors in parentheses.

${ }^{* * *} \mathrm{p}<0.01,{ }^{* *} \mathrm{p}<0.05,{ }^{*} \mathrm{p}<0.1$.

\section{References}

Adams-Prassl, A., Boneva, T., Golin, M., \& Rauh, C. (2020). Inequality in the impact of the coronavirus shock: Evidence from real time surveys. Journal of Public Economics, 189, 104245. https://doi.org/10.1016/j.jpubeco.2020.104245.

Alon, T. M., Doepke, M., Olmstead-Rumsey, J., \& Tertilt, M. (2020). The impact of COVID-19 on gender equality. National Bureau of Economic Research Working Paper No., 26947.

Angrist, J. D., \& Pischke, J. S. (2008). Mostly harmless econometrics: An empiricist's companion. Princeton University Press.

Belot, M., Choi, S., Jamison, J. C., Papageorge, N. W., Tripodi, E., \& van den BroekAltenburg, E. (2020). Six-Country Survey on Covid-19, IZA DP No. 13230, May 2020.

Blinder, A. S. (1973). Wage discrimination: Reduced form and structural estimations. Journal of Human Resources, 8, 436-455.

Cajner, T., Crane, L.D., Decker, R.A., Grigsby, J., Hamins-Puertolas, A., Hurst, E., Kurz, C., \& Yildirmaz, A. (2020). The US labor market during the beginning of the pandemic recession. National Bureau of Economic Research Working Paper No. 27159.

Croson, R., \& Gneezy, U. (2009). Gender differences in preferences. Journal of Economic Literature, 47(2), 448-474. https://doi.org/10.1257/jel.47.2.448.

Doepke, M., \& Tertilt, M. (2016). Families in Macroeconomics. Chapter 23 of Handbook of Macroeconomics (Vol. 2) North Holland: Elsevier.

Duflo, E. (2012). Women empowerment and economic development. Journal of Economic Literature, 50(4), 1051-1079. https://doi.org/10.1257/jel.50.4.1051.

Farré, L., Fawaz, Y., González, L., \& Graves, J. (2020). How the COVID-19 Lockdown Affected Gender Inequality in Paid and Unpaid Work in Spain. IZA Discussion Paper No. 13434, IZA Institute of Labor Economics.

Foucault, M., \& Galasso, V. (2020). Working after covid-19: Cross Country evidence from real-time survey data. Science Po CEVIPOF Research Note \#9/ May 2020.
Hoynes, H., Miller, D. L., \& Schaller, J. (2012). Who suffers during recessions?. Journal of Economic Perspectives, 26(3), 27-48.

Hupkau, C., \& Petrongolo, B. (2020). COVID-19 and gender gaps: Latest evidence and lessons from the UK. https://voxeu.org/article/covid-19-and-gender-gapslatest-evidence-and-lessons-uk

Jann, B., \& Zürich, E. (2008). The Blinder-Oaxaca decomposition for linear regression models. The Stata Journal, 8(4), 453-479.

Kureishi, W., \& Wakabayashi, M. (2013). What motivates single women to save? The case of Japan. Rev Econ Household, 11(4), 681-704. https://doi.org/10.1007/ s11150-013-9191-z.

Lee, J., \& Pocock, M. L. (2007). Intrahousehold allocation of financial resources: Evidence from South Korean individual bank accounts. Rev Econ Household, 5(1), 41-58. https://doi.org/10.1007/s11150-007-9004-3.

Oaxaca, R. (1973). Male-female wage differentials in urban labor markets. International Economic Review, 14(3), 693. https://doi.org/10.2307/2525981.

OECD (2020), Evaluating the initial impact ofCOVID-19 containment measures on economic activity, The Organisation for Economic Co-operation and Development (OECD), http://www.oecd.org/coronavirus/policy-responses/ evaluating-the-initial-impact-of-covid-19-containment-measures-oneconomic-activity-b1f6b68b/

Sevilla, A., \& Smith, S. (2020). Baby Steps: The Gender Division of Childcare during the COVID-19 Pandemic. IZA Discussion Paper No. 13302, IZA Institute of Labor Economics.

Sumner, A., Hoy, C., \& Ortiz-Juarez, E. (2020). Estimates of the Impact of Covid-19 on Global Poverty. In WIDER Working Paper 2020/43. Helsinki: UNU-WIDER.

United Nations (UN) (2019). Report of the Secretary-General. Special edition: progress towards the Sustainable Development Goals. https://undocs.org/E/ 2019/68 